\title{
IAMJ
}

INTERNATIONAL

AYURVEDIC

MEDICAL JOURNAL

\section{MANAGEMENT OF SWITRA WITH SHAMANA AUSHADIS - A CASE STUDY}

\section{$\underline{\text { Ajay Kumar Dharmabrat Acharya }}{ }^{1}, \underline{\text { Prasan V Joshi }}^{2}$}

${ }^{1}$ B.A.M.S, $2^{\text {nd }}$ year P.G Scholar, Department of PG Studies in Kayachikitsa, SVM Ayurvedic Medical College \& PG Research Centre, Ilkal, Bagalkot, Karnataka, India

${ }^{2}$ B.A.M.S, M.D (Ayu) Professor \& HOD, Department of PG Studies in Kayachikitsa, SVM Ayurvedic

Medical College \& PG Research Centre, Ilkal, Bagalkot, Karnataka, India

Corresponding Author:ajayacharya010.aa@gmail.com

\section{https://doi.org/10.46607/iamj4709102021}

(Published Online: October 2021)

Open Access

(C) International Ayurvedic Medical Journal, India 2021

Article Received:03/09//2021 - Peer Reviewed:22/09/2021 - Accepted for Publication:24/09/2021

\section{Check for updates}

\begin{abstract}
As the increasing population is much concerned about beauty, so several cosmetic products are also increasing in the market. Switrais not only a pathological but also a very serious sociological problem. It can be compared with vitiligo in contemporary science having a prevalence of $0.25 \%$ in India. In Ayurveda, it is explained along with kustha roga $a^{1}$, but it is not explained under Mahakustha \& kshudrakustha. In a conventional system of medicine, there is no perfect aetiology and treatment for vitiligo. But in Ayurveda, many lines of treatment are explained like shodhana \& shamanaas. As it may be autoimmune \& heredity also takes a long time to treat, so the patient needs more patience for treatment. After 10 months of treatment with proper follow up this case shows up to $90 \%$ cure of switra through Ayurveda that too only with Shamana Aushadha.
\end{abstract}

Keywords- switra, a case study on switra, shamanaaushadhis

\section{INTRODUCTION}

In the busy world, people spend more money to maintain the beauty of their skin. Skin is the $1^{\text {st }}$ organ, which is exposed to the environment physically, chemically \& biologically. Any pathology which is 
not treated properly will reflect on skin and in children it will be more progressive. Condition like psoriasis, eczema, vitiligo etc. is a psychosomatic disease in which a patient is isolated from society, because of disfigurement of the skin \& he or she may undergo depression. Now a day's society is surrounded by skin pathologies. Though, Internet \& other Media's advertising number of remedies and without any detailed information of that remedies people are blindly buying the skin disorders unknowingly. Skin disease is explained from the Vedic period. In Ayurveda, Switra is a disease that affects the person socially because it causes depigmentation over the skin. Switra is a skin disease with lakshans like shweta varma mandala, alpa kandu andaparisravi ${ }^{2}$ (without secretion). There is no successful and significant result for switra in the conventional system of medicine. Our acharya's explained various suitable lines of treatment like shodhana and shamana. But it takes more time as well as patience for a complete cure. Due to differences in lifestyle, the prognosis differs from individual to individual.

\section{A brief history of the patient}

11-year female patient, Muslim by religion came with complaints of whitish patch on both the iliac region in the last 6 months, the patient was normal before 6 months but gradually developed itching sensation by using tight clothes with small patch ${ }^{3}$.Her mother noticed that gradually it becomes whitish with increasing itching. She neglected the symptoms, gradually she noticed that the lesion becoming big .so she consulted a local doctor and took medication (history unavailable) but did not get any satisfactory result. Due to this patient consulted RPK Ayurvedic hospital for further treatment.

Family history- Nothing significant all are said to be healthy in her family.

Local examination- Lesion on both iliac region and asymmetrically distributed

\section{Lesion:}

There are uneven white patches with nondifferentiated size and itching sensation, absence of inflammation and discharge.

\section{Samprapti}

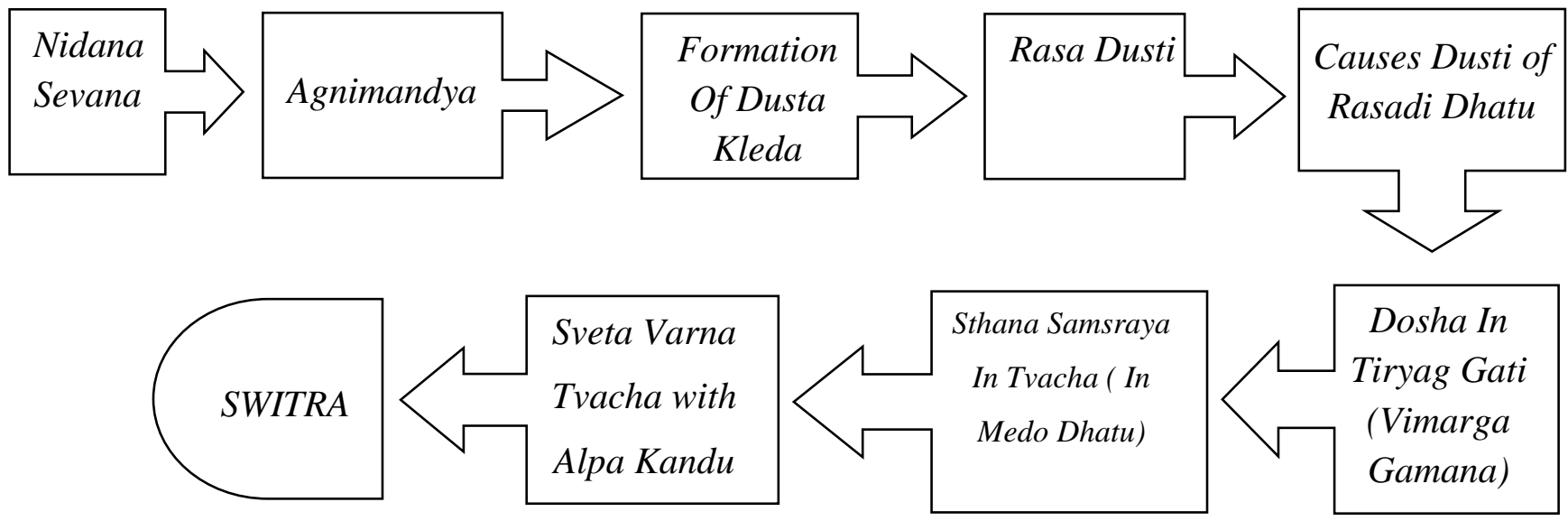

6.Chikitsa
\begin{tabular}{|l|l|l|}
$\boldsymbol{1}$ & st \\
\hline day & MHAMANA AUSHADHIS & MATRA \\
\hline 1 & Tab Chitrakadi vati & 2 BD BF with sukhoshna Jala \\
\hline 2 & Swayambhu guggulu & 2 BD AF \\
\hline 3 & Syr. Khadirarista & As ananupana for swayambhu guggulu \\
\hline
\end{tabular}




\begin{tabular}{l|l|l|}
\multicolumn{2}{l}{$\mathbf{1}^{\text {st }}$} & follow up \\
\hline 1 & Manibhadra Guda & $1 / 2$ tsf OD BF with sukhoshna Jala \\
\hline 2 & Cap white care & 2 BD AF with sukhoshna Jala \\
\hline
\end{tabular}

\section{$2^{\text {nd }}$ follow up}

\begin{tabular}{|l|l|l|}
\hline 1 & Tab Chandraprabha Vati & 2 BD B/F With sukhoshna Jala \\
\hline 2 & Lucodna Lepa & L/A After Sit-In Sun Light For 5-10 Mins \\
\hline 3 & Tab Pigmento & 2BD A/F With sukhoshna Jala \\
\hline 4 & Manibhadra Guda & 1/2 Tsf B/F With sukhoshna Jala \\
\hline
\end{tabular}

\section{$3^{\text {rd }}$ follow up}

\begin{tabular}{|l|l|l|}
\hline 1 & Tab Pigmento & 2 BD A/F With sukhoshna Jala \\
\hline 2 & Tab Arogyavardini Vati & 2 BD B/F With sukhoshna Jala \\
\hline 3 & Lucodna Lepa & L/A After Sit In Sun Light For 5-10 Mins \\
\hline
\end{tabular}

\section{$4^{\text {th }}$ follow up}

1 Cap whit care

1BD A/F With sukhoshna Jala

\section{$5^{\text {th }}$ follow up \\ 1 Tab Pigmento \\ 2 Lucodna Lepa \\ 3 Manibhadra Guda \\ 1 BD A/F With sukhoshna Jala \\ L/A After Sit In Sun Light For 5-10 Mins \\ 1tsf OD With sukhoshna Jala}

\section{$6^{\text {th }}$ follow up}

1 Madhusnuhi Rasayana

1tsf OD ES with sukhoshna Jala

\section{$7^{\text {th }}$ follow up}

\begin{tabular}{|l|l|l|}
\hline 1 & Tab Pigmento & 1BD A/F With sukhoshna Jala \\
\hline 2 & ManibhadraGuda & $1 / 2$ tsf B/F With sukhoshna Jala \\
\hline 3 & LucodnaLepa & L/A \\
\hline
\end{tabular}

\section{Observation}

\begin{tabular}{|c|c|c|c|c|}
\hline \multirow[t]{2}{*}{ SN } & \multirow[b]{2}{*}{ FOLLOW-UPS } & \multicolumn{3}{|l|}{ COMPLAINTS } \\
\hline & & VARNA & SRAVA & KANDU \\
\hline 1 & $1^{\text {st }}$ day & Shweta & Absent & Present \\
\hline 2 & $1^{\text {st }}$ follow-up & Shweta & Absent & Present \\
\hline 3 & $2^{\text {nd }}$ follow-up & Spikes of repigmentation started at the right ileac region & Absent & Mildly Reduced \\
\hline 4 & $3^{\text {rd }}$ follow-up & Spikes of repigmentation starts & Absent & Mildly Reduced \\
\hline 5 & $4^{\text {th }}$ follow-up & Spikes of repigmentation & Absent & Reduced \\
\hline 6 & $5^{\text {th }}$ follow-up & $\begin{array}{l}\text { Repigmentation of Skin Colour In Right Iliac Region \& } \\
\text { Spikes of repigmentation }\end{array}$ & Absent & Absent \\
\hline 7 & $6^{\text {th }}$ follow-up & Spikes of hypopigmentation remained & Absent & Absent \\
\hline 8 & $7^{\text {th }}$ follow-up & Spikes of hypopigmentation remained & Absent & Absent \\
\hline 9 & \multicolumn{4}{|c|}{ The patient is still under treatment } \\
\hline
\end{tabular}




\section{Result}

\begin{tabular}{|l|l|l|l|}
\hline SN & COMPLAINTS & BT & AT \\
\hline 1 & Varna & Shweta & Spikes Of Hypopigmentation remained \\
\hline 2 & Srava & Absent & Absent \\
\hline 3 & Kandu & Present & Absent \\
\hline
\end{tabular}

\section{DISCUSSION}

Tab Chitrakadi Vati' ${ }^{\text {-It }}$ act as agni deepaka, pachaka, kaphaghna \& medoghna. Swayambhu Guggulu ${ }^{4}$ It is vyadhi pratyaneeka \& directly indicated for switra. Khadirarista ${ }^{\mathbf{8}}$-khadira is best kusthagna, so it is used as anupana for swayambhu guggulu. It is also containing kaphaghna \& medoghna dravyas.

Manibhadra Guda ${ }^{5}$-As the patient was not willing to take any shodhana, so it is given as nitya virechana and it is indicated for switra also. Whit Care-It contains kakaudumbara, bakuchi, majistha etc. which are switragnhna. Tab Chandraprabha Vati ${ }^{7}$-It contains guggulu \& shilajatu, both are medoghna, kaphagnha and it is indicated for kustha also. As in switra meda and kapha are involved it plays an important rule as dosha pratyanika and helps for samprapti vighatana.

Lucodna Lepa- It is a preparation with ingredients like kustharakshasa taila, aragvadaitaila, manashila, bakuchi etc. Which are kusthagna and shwitraghnas. After applying patient was directed to sit in the sunlight for 5-10 min which helped for activation of melanocytes. Tab Pigmento- The contents of this tablet are tamra bhasma, bakuchi, shilajatu which are kaphagna, medoghna \& switraghna. So, it acts as vyadhi pratyanika.

Arogyavardini Vati- It contains katuki which is bhedaka. As in switra doshas are deeply seated so it helps for removing alpa dosha repeatedly. It also contains tamra bhasma, which is switraghna. According to contemporary science decreasing serum copper level leads to vitiligo ${ }^{\mathbf{1 0}}$. Madhusnuhi Rasayana ${ }^{6}$ - As after shodhana, rasayana is advised, so after nitya shodhana patient is advised to take Madhusnuhi Rasayana which is specifically indicated for kustha and switra.

\section{CONCLUSION}

Overall, by shaman aushadis \& rasayana therapy with proper follow-up patient got $90 \%$ relief but still spikes of hypopigmentation remained in both the lesion with a complete decrease of itching sensation. Still, the patient is under the treatment. Bakuchi is the enemy of switra, and it is the main content in all most all formulations which are used in this case.

\section{REFERENCE}

1. Agnivesa, Charak samhita, Ayurveda Deepika commentary by Chakrapani, Chaukhambha Orientalia, Varanasi, Edition-2019 P.454.

2. Susruta, Nivandha sangraha vyakhya by Dhalana \& Naya Chandrika by Gayadasa edited by Acharya PriyavratSharma, Chaukhambha Orientalia, reprint 2019, p.287.

3. Susruta, Nivandha sangraha vyakhya by Dhalana \& Naya Chandrika by Gayadasa edited by Acharya PriyavratSharma, Chaukhambha Orientalia, reprint 2019, p.287.

4. Bhavmishra, Bhavaprakash, Bhisagratna Brahmasankara Mishra, Vidyotini tika, Chaukhambha Sanskrit bhavan, edition-2020, Madhyama khanda, p.537

5. Vagbhat Acharya, Asthanga Hridaya, Sarvangasundara tika by Aruna Datta and Ayurveda Rasayana tika by Hemadri, edited by Bhisagacharya Hari shastriParadakaraVaidya, Chaukhambha Orientalia, reprint 2019, P 713

6. Dr Ramnivas Sharma \& Dr Surendra Sharma, Sahasrayoga, ChaukhambhasamskruthaPratishthan, reprint 2004, p. 183

7. Acharya SharangdharaSarangadhara samhita, Jiwa Prada hindi commentary, by Dr Smt. Shailaja Srivastava, ChaukhambhaOrientalia, edition 1996, p.200,201

8. Acharya SharangdharaSarangadhara samhita, Jiwa Prada hindi commentary, by Dr Smt. Shailaja Srivastava, ChaukhambhaOrientalia, edition 1996, p.252

9. Agnivesa, Charak samhita, Ayurveda Deepika commentary by Chakrapanidatta, edited by VaidyaYadavji 
Trikamji acharya, Chaukhambha Prakashana, Varanasi, Edition-2013 P.520.

10. Archana S, Rangappa V, Savitha T, Jayadev B, Kushalappa P, Ashwini P. Does copper have a role in vitiligo? Analysis of tissue and serum copper in vitiligo. Pigment International vol-8. issue-1. January-April 2021.

ANNEXURE
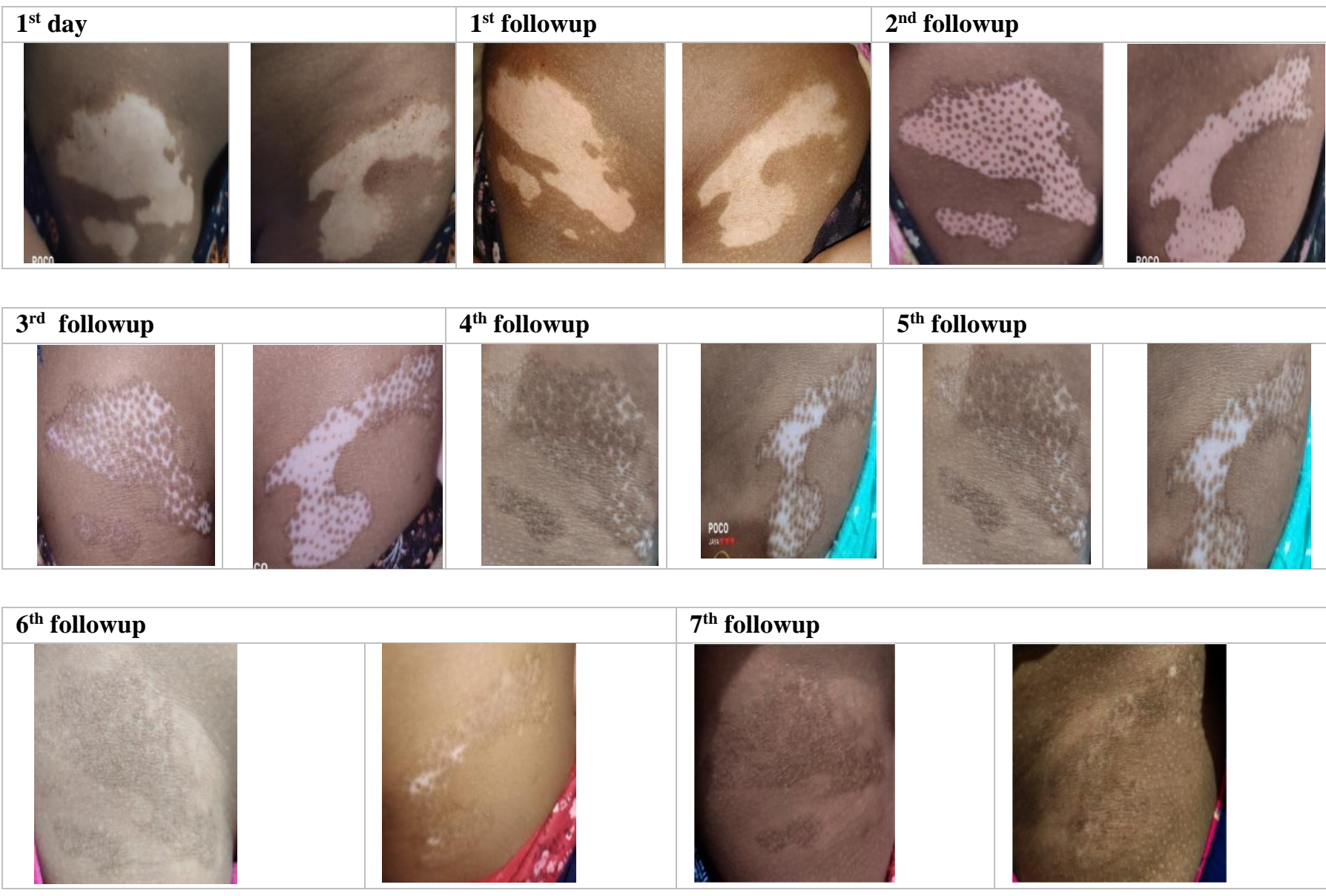

\section{Source of Support: Nil \\ Conflict of Interest: None Declared}

How to cite this URL: Ajaya kumar Dharmabrat Acharya \& Prasan V Joshi: Management Of Switra With Shaman Aushadis - A Case Study. International Ayurvedic Medical Journal \{online\} 2021 \{cited October 2021\} Available from: http://www.iamj.in/posts/images/upload/2578_2582.pdf 